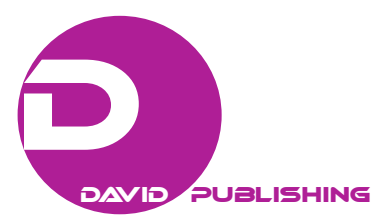

\title{
Access to Credit by SMEs and Implications for Economic
}

\section{Growth in Nigeria}

\author{
Afolabi Babatunde, Ekpenyong Keziah Yemisi, Akomolafe John, Awoyemi Olanike Bosede \\ Afe Babalola University, Ado Ekiti, Nigeria
}

\begin{abstract}
The purpose of this study is to examine the impact of credit availability to SMEs on the economic growth in Nigeria. The study period was from 1981 to 2012. Vector autoregressive model was employed to avoid the problem of endogenity. The results show that though inflation has a negative effect on SMEs financing, it still significantly influences economic growth. This paper therefore concludes that there is a need for government to intensify efforts to increase SMEs financing in the country through the introduction of a special intervention fund for SMEs.
\end{abstract}

Keywords: small and medium scale enterprises, SMEs financing, economic growth, Nigeria, commercial banks

\section{Introduction}

Small and medium scale enterprises (SMEs) play an important role in the development process of every economy, especially the developing nations. It is the life and bedrock of every economy. It is a major source of employment generation (Organization for Economic Co-Operation and Development (OECD), 2004). According to Savlovschi and Robu (2011), two thirds of the newly created jobs are owed to the small and medium sector. Also, it is the bed seeds for indigenous entrepreneurship and that generate all the small investments which otherwise would not have taken place (Aryeetey \& Ahene, 2004). Also, SMEs provide the first step for development in the economies towards industrialization. They also significantly affect income distribution, tax revenue, employment generation, and resources utilization in an economy (Subhan, Mehmood, \& Sattar, 2013). Also, Savlovschi and Robu (2011) claimed that SMEs are the sources from where large enterprises grew from, and they are the sources of new innovative ideas needed for the development of the economy. They help to promote competition and to bring new products to the market (Robu, 2013).

Aware of the importance of SMES in the developing process of an economy, there is the new drive towards promoting and encouraging the development of SMEs across the world (OECD, 2004). According to Business Statistics (2016), over 99\% of businesses in UK are SMEs, totaling about 5.5 million in 2016. In USA, SMEs are the backbone of the economy, consisting of 99 percent of all firms in the country, and employing over 50 percent of private sector employees (Capital for Globalizing Companies, 2015) in Nigeria. The number of SMEs in 2013 is 72,838, while of micro business is 36,994,578 (Small and Medium Enterprise Development

Afolabi Babatunde, Ph.D., senior lecturer, Afe Babalola University, Ado Ekiti, Nigeria.

Ekpenyong Keziah Yemisi, Afe Babalola University, Ado Ekiti, Nigeria.

Akomolafe Kehinde John, lecturer, Afe Babalola University, Ado Ekiti, Nigeria.

Awoyemi Olanike Bosede, lecturer, Afe Babalola University, Ado Ekiti, Nigeria.

Correspondence concerning this article should be addressed to Afolabi Babatunde, Killometer 85 Afe Babalola Way, Afe Babalola University, PMB 5454, Ado Ekiti, Nigeria. 
Agency of Nigeria (SMEDAN) \& National Bureau of Statistics, 2013). The development of SMEs in Nigeria is very low when compared to those of other developed nations. SMEs in Nigeria are faced with many challenges which hamper its growth. One of these is access to finance. According to Onugu (2005), the problems SMEs are facing in Nigeria are management, access to finance, infrastructure, government policy inconsistencies and bureaucracy, environmental factors, multiple taxes and levies, access to modern technology, unfair competition, marketing problems, and non-availability of raw materials locally. Also, Okpara (2011) found out that the lack of financial support is a major factor that hinders the growth and survival of SMEs in Nigeria. It is in this regard that this study aims to examine the implication of access to credit by SMEs on economic growth in Nigeria.

\section{Literature Review}

There have been various attempts to study the relationship between SMEs and economic growth in the literature. Akingunola (2011) examined the relationship between SMEs financing options and economic growth in Nigeria using investment as proxy for economic growth. The result shows that SMEs financing is positively related to economic growth. Also, Adebisi, Sunday, and Ofuani (2015) examined the financial challenges that SMEs are facing and its effects on their performance in Lagos state. The study used primary data which were collected through administration of questionnaire to 222 respondents. The study shows that financial challenges rank as the highest among the challenges inhibiting the performance of SMEs in Lagos state, Nigeria. Also, Afolabi (2013) examined the growth effect of small and medium enterprises (SMEs) financing in Nigeria between 1980 and 2010. Using Ordinary Least Square (OLS), the result shows that SMEs financing was positively related to economic growth.

Nwachukwu (2012) used primary data collected from 100 SMEs which were randomly selected across some states in Nigeria to access to the role of entrepreneurship in economic development of Nigeria. The result shows that SMEs have not performed up to expectation in its effects on the country's economic development. Ebiringa (2011) examined the contributions of SMEs and large firms to economic activities in Nigeria. The results showed that SMEs provide more of the employment opportunities than the large scale firms. The result also shows that SMEs are not significant in its contribution to manufacturing sector output growth but large firms are. Olowe, Moradeyo, and Babalola (2013) examined the impact of microfinance bank on SMEs growth in Oyo State, Nigeria. The results from this study showed that financial services obtained from MFBs have a positive significant impact on MSEs growth in Nigeria. The results also show that duration of loan has a positive impact on SMEs growth but not statistically significant.

Abereijo and Fayomi (2005) review innovative approach to financing small and medium industries equity investment scheme in Nigeria. They found out that challenges that banks in Nigeria face in the implementation of Small and Medium Industries Equity Investment Scheme (SMIEIS) include challenges that relate to deal flow, investment structuring, monitoring/value enhancement, and liquidity and exit strategies. Safiriyu and Njogo (2012) examined the impact of small and medium scale enterprises on employment in Lagos State, Nigeria. The result shows that SMEs have positively contributed to employment generation in Nigeria.

\section{Defining Small and Medium Enterprise}

Various definitions exist on the definitions of SMEs by different countries and organization. According to the European Commission (2003), SMEs refer to companies with fewer than 250 employees, a turnover below $€ 50$ million, and a balance sheet total of less than 43 Million Euro. According to International Finance 
Corporation (2006), an enterprise is said to be micro if the number of its employees is below 10, total assets are less or up to $\$ 100,000$ or its equivalent, and total annual sales are less or up to $\$ 100,000$ or its equivalent. It is small if the number of its employees is more than 10 but less or equal to 50, total assets are greater than $\$ 100,000$ but less than or equal to $\$ 3 \mathrm{~m}$ or its equivalent, and total annual sales are less or up to $\$ 3 \mathrm{~m}$ or its equivalent. It is medium if its employees are more than 50 but less or equal to 300 , total assets are greater than $\$ 3 \mathrm{~m}$ but less than or equal to $\$ 15 \mathrm{~m}$ or its equivalent, and total annual sales are greater than $\$ 3 \mathrm{~m}$ but less than or equal to $\$ 15 \mathrm{~m}$ or its equivalent.

In Nigeria, the definition of micro, small, and medium enterprises is addressed in the National Policy on MSMEs, and uses employment and assets as the basis for its classification (SMEDAN and NBS, 2013). An enterprise is said to be micro if the number of employees is less than 10, and total assets (excluding land and building) are less than N5 million. It is small that the number of employees is between 10 and 49, and total assets excluding land and building) are between N5 million and less than N50 million. It is medium if employees is between 50 and 199, and total assets excluding land and building) are between N50 million and less than N500 million.

\section{Distribution of Micro, Small, and Medium Enterprises by State in Nigeria}

Table 1 shows that Lagos State has the highest population of small enterprises, medium enterprises, and micro-enterprises in the country. This is as expected given the fact that the state is the hub of economic activities in the country. Kano State is followed in term of small enterprises, while Oyo State is second in term of micro and medium enterprises. This shows that population of a state does not necessarily determine the amount of enterprises as it attracts. The concentration of micro and medium enterprises in Oyo State might have been influenced by its proximity to Lagos state which is a close source of raw materials.

Table 1

\section{Distribution of Small and Medium Enterprises by State}

\begin{tabular}{llll}
\hline State & Small & Medium & Micro \\
\hline Abia & 1,769 & 40 & 904,721 \\
Akwa-Ibom & 898 & 195 & $1,319,607$ \\
Anambra & 1,620 & 117 & $1,223,395$ \\
Bauchi & 2,039 & 27 & 944,503 \\
Bayelsa & 354 & 72 & 541,332 \\
Benue & 1,146 & 22 & $1,479,145$ \\
Cross River & 1,126 & 168 & 921,256 \\
Delta & 1,444 & - & $1,536,158$ \\
Ebonyi & 1,206 & 4 & 577,216 \\
Edo & 1,879 & 118 & 898,084 \\
Ekiti & 903 & 126 & 964,179 \\
Enugu & 812 & 99 & $1,064,893$ \\
Gombe & 1,043 & 65 & 527,230 \\
Imo & 1,259 & 135 & $1,296,386$ \\
Jigawa & 1,022 & 75 & 820,001 \\
Kaduna & 2,712 & 170 & $1,635,453$ \\
Kano & 7,790 & 496 & $1,794,358$ \\
Katsina & 1,256 & 99 & $1,216,604$ \\
Kebbi & 898 & 91 & 692,104 \\
\hline
\end{tabular}


Table 1 continued

\begin{tabular}{llll}
\hline State & Small & Medium & Micro \\
\hline Kogi & 827 & 17 & 967,431 \\
Kwara & 164 & 62 & 717,909 \\
Lagos & 11,044 & 619 & $3,224,324$ \\
Nasarawa & 1,098 & 22 & 382,086 \\
Niger & 1,258 & 100 & 977,240 \\
Ogun & 1,690 & 104 & $1,165,848$ \\
Ondo & 1,805 & 194 & $1,026,770$ \\
Osun & 2,247 & 25 & $1,356,174$ \\
Oyo & 7,468 & 519 & $1,864,954$ \\
Plateau & 2,070 & 110 & 786,504 \\
Rivers & 2,981 & 41 & $1,749,911$ \\
Sokoto & 631 & 210 & 700,106 \\
Taraba & 891 & 69 & 513,973 \\
Zamfara & 577 & 16 & 722,360 \\
Fct & 2,244 & 446 & 482,365 \\
Total & 68,168 & 4,670 & $36,994,578$ \\
\hline
\end{tabular}

Source: SMEDAN and NBS (2013).

\section{Trend in Percentage Share of SMEs in Deposit Money Banks' Total Credit to the Economy}

Figure 1 shows that the rate of percentage share of SMEs in total credit granted to the economy by deposit money banks in Nigeria has experienced up and down overtime. From 3.2\% in 1984, it rose significantly to 20.2\% in 1988. A sharp increase was also experienced between 1990 and 1992 as it stood at $49 \%$. Since then, it has remained on the decline state with some marginal increase intermittently.

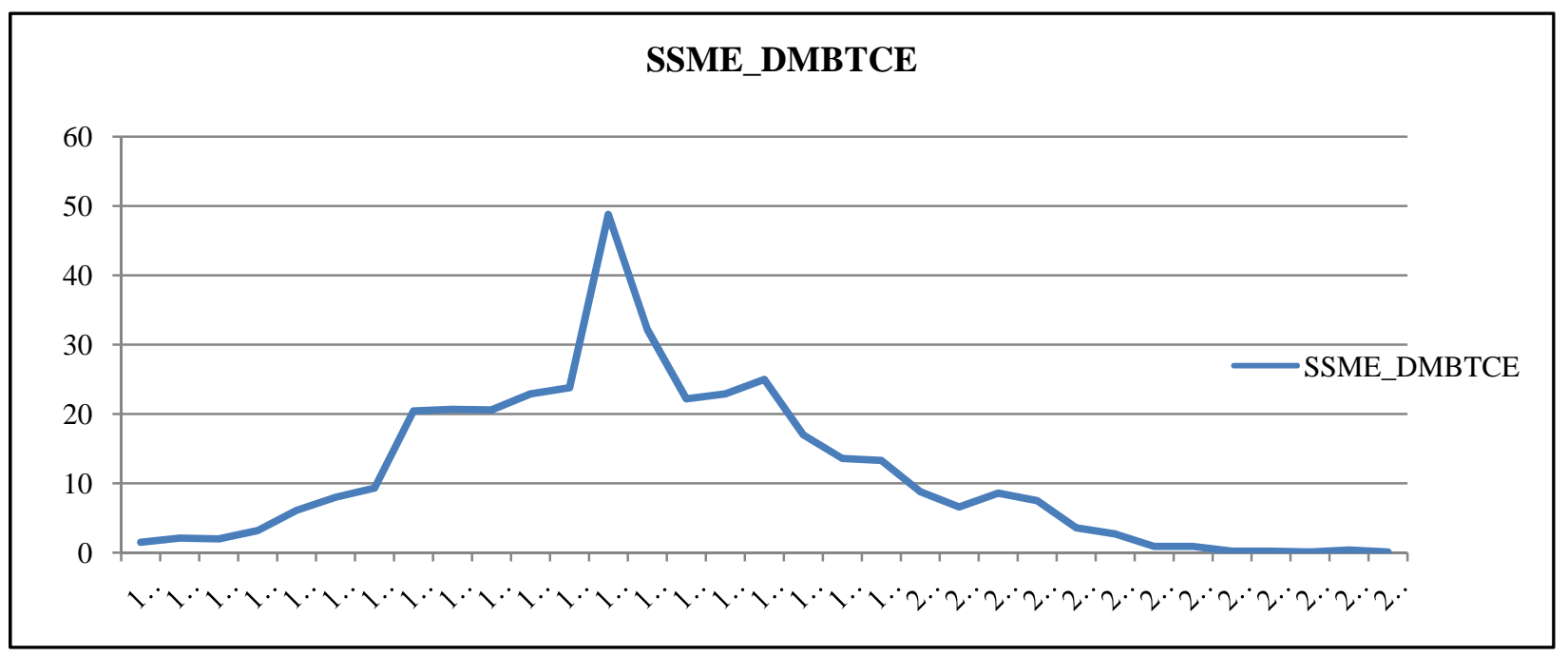

Figure 1. Trend in percentage share of SMEs in deposit money banks' total credit to the economy (1980-2012). Source: Author's computation 2016.

\section{Methodology}

\section{Data Type and Sources}

This paper used the secondary data which were sourced from the Central Bank of Nigeria 2013 Statistical Bulletin and World Bank data bank online. The data span the period from 1981 to 2012. 


\section{The Model}

This paper uses a vector autoregressive (VAR) model. Unlike other authuors who have worked on the same issue, we argued that the relationship between economic growth and SMEs financing may pose some endogeneity problems. Also, we argued that inflation may play a role on the effect of SMEs financing on economic growth. Hence, we adopt a VAR model to identify the feedbacks from the variables in the model. The VAR model is presented below.

$$
\begin{aligned}
& G D P_{t}=C_{1}+\sum_{i=1}^{p} \sigma_{i} G D P_{t-1}+\sum_{j=1}^{p} \pi_{j} \ln C L S M E_{t-1}+\sum_{u=1}^{p} \varphi_{u} I N F_{t-1}+\sum_{w=1}^{p} \delta_{w} \text { Money }_{t-1}+\sum_{k=1}^{p} \beta_{f} I N T_{t-1}+\varepsilon_{1 t} \\
& \operatorname{lnCLSME} E_{t}=C_{2}+\sum_{i=1}^{p} \sigma_{i} \operatorname{lnCLSME} E_{t-1}+\sum_{j=1}^{p} \pi_{j} G D P_{t-1}+\sum_{u=1}^{p} \varphi_{u} \operatorname{INF}_{t-1}+\sum_{w=1}^{p} \delta_{w} \text { Money }_{t-1}+\sum_{k=1}^{p} \beta_{f} \operatorname{INT}_{t-1}+\varepsilon_{2 t} \\
& I N F_{t}=C_{3}+\sum_{i=1}^{p} \sigma_{i} I N F_{t-1}+\sum_{j=1}^{p} \pi_{j} \operatorname{SDP}_{t-1}+\sum_{u=1}^{p} \varphi_{u} \operatorname{lnCLSME} E_{t-1}+\sum_{w=1}^{p} \delta_{w} \text { Money }_{t-1}+\sum_{k=1}^{p} \beta_{f} I N T_{t-1}+\varepsilon_{3 t} \\
& \text { Money }_{t}=C_{4}+\sum_{i=1}^{p} \sigma_{i} \operatorname{MONEY}_{t-1}+\sum_{j=1}^{p} \pi_{j} \operatorname{GDP}_{t-1}+\sum_{u=1}^{p} \varphi_{u} \operatorname{lnCLSME}_{t-1}+\sum_{w=1}^{p} \delta_{w} \operatorname{INF}_{t-1}+\sum_{k=1}^{p} \beta_{f} I N T_{t-1}+\varepsilon_{4 t}
\end{aligned}
$$

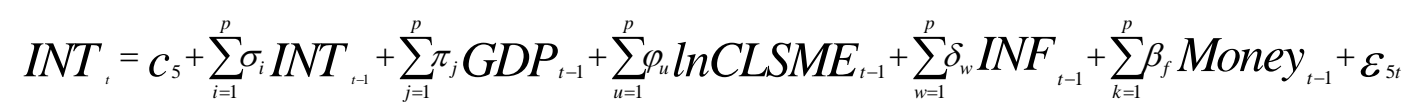

where GDP refers to the growth of gross domestic product, and was used as proxy for economic growth, and it was sourced from World Bank data. InCLSME is log of commercial bank loan to small and medium enterprise, and it was sourced from CBN. Also, inflation, interest rate, and money supply were added as control variables. INF is inflation; it was sourced from World Bank data. Money is growth of broad money supply; it was sourced from World Bank data. INT is nominal interest rate; it was also sourced from World Bank.

\section{Estimation Technique}

In order to estimate the VAR, the time series properties were first examined using ADF unit root test. This was to ascertain if the series have unit root or not. If the series are not stationary at level, it is then tested at the first difference of the series. After this, a co-integration test uses Johnasen co-integration test. If the series are co-integrated, we estimate a vector error correction model; if not, we estimate the unrestricted VAR in their difference. However, if the series are stationary at level, a VAR at the level of the variables can be estimated.

\section{Results and Discussion}

\section{Unit Root Test}

The result of the stationarity test is presented and discussed in this section. The ADF is tested based on the assumption of intercept and trend. The test was carried out using optimal lag length of 7. As shown in Table 2, all the series were stationary at their level. Given this, we estimate the VAR at level.

\section{Results of the VAR Model}

In this section, we will only present a discussion of the results on economic growth and SMEs financing.

Economic growth. The effect of SMEs financing and other control variables on economic growth are discussed in this section. As shown in Table 3, there is a positive relationship between the SMEs financing, proxied by commercial bank credit to SMEs, and the growth of the economy, proxied by the growth of GDP. This shows that SMEs financing positively influenced economic growth. Also, the growth of money supply has 
a negative effect on economic growth. This is against the expected result. However, the growth of money supply can increase the inflation rate in the country, which will eventually negatively affect economic growth. The result is also significant. Interest rate also has a positive relationship with the growth of the economy. As expected, there is a negative relationship between inflation and the growth rate of the economy. The result is also significant.

Table 2

ADF Test in Level Data

\begin{tabular}{|c|c|c|c|c|c|c|}
\hline \multirow{4}{*}{ Variables } & \multicolumn{5}{|c|}{ At level } & \multirow{4}{*}{-Remark } \\
\hline & \multicolumn{5}{|c|}{ Intercept and trend } & \\
\hline & \multicolumn{3}{|c|}{ Critical value } & \multirow{2}{*}{-T-Stat } & \multirow{2}{*}{ Prob. } & \\
\hline & $1 \%$ & $5 \%$ & $10 \%$ & & & \\
\hline GGDP & -4.284580 & -3.562882 & -3.215267 & -5.222650 & $0.0010 * * *$ & $\mathrm{I}(0)$ \\
\hline LCLSME & -4.616209 & -3.710482 & -3.297799 & -5.618661 & $0.0017^{* * *}$ & $\mathrm{I}(0)$ \\
\hline GMONEY & -4.296729 & -3.568379 & -3.218382 & -3.671635 & $0.0403^{* *}$ & $\mathrm{I}(0)$ \\
\hline INT & -4.356068 & -3.595026 & -3.233456 & -4.176064 & $0.0148 * *$ & $\mathrm{I}(0)$ \\
\hline INFLATION & -4.296729 & -3.568379 & -3.218382 & -3.449779 & $0.0637 *$ & $\mathrm{I}(0)$ \\
\hline
\end{tabular}

Note. ${ }^{* * *}$ indicates stationary at $1 \%$; **indicates stationary at $5 \%$; *indicates stationary at $10 \%$.

Source: Author's computation 2017.

Table 3

Unrestricted VAR Result

\begin{tabular}{|c|c|c|c|c|c|}
\hline & GGDP & LCLSME & GMONEY & INT & INFLATION \\
\hline & 0.020779 & 677.0154 & -0.442343 & 0.032032 & -0.709216 \\
\hline \multirow[t]{3}{*}{ GGDP } & $(0.18637)$ & $(748.850)$ & $(0.35579)$ & $(0.10637)$ & $(0.38845)$ \\
\hline & [ 0.11149] & [ 0.90407] & [-1.24325] & [ 0.30113] & {$[-1.82578]$} \\
\hline & 6.88E-05 & 0.201454 & $-9.36 \mathrm{E}-06$ & $1.96 \mathrm{E}-05$ & -8.19E-05 \\
\hline \multirow[t]{3}{*}{ LCLSME } & $(4.9 \mathrm{E}-05)$ & $(0.19574)$ & $(9.3 \mathrm{E}-05)$ & $(2.8 \mathrm{E}-05)$ & $(0.00010)$ \\
\hline & [ 1.41140$]$ & [ 1.02922] & {$[-0.10062]$} & [0.70399] & {$[-0.80694]$} \\
\hline & -0.017384 & -524.6723 & 0.552873 & 0.006355 & 0.066392 \\
\hline \multirow[t]{3}{*}{ GMONEY } & $(0.09243)$ & (371.387) & $(0.17645)$ & $(0.05275)$ & $(0.19265)$ \\
\hline & [-0.18808] & {$[-1.41274]$} & [ 3.13324] & [0.12047] & [0.34463] \\
\hline & 0.591102 & 1791.448 & 1.225025 & 0.442653 & 0.904983 \\
\hline \multirow[t]{3}{*}{ INT } & $(0.32437)$ & (1303.32) & $(0.61924)$ & $(0.18513)$ & $(0.67606)$ \\
\hline & [ 1.82234$]$ & [ 1.37453$]$ & [ 1.97829] & [2.39101] & [1.33861] \\
\hline & -0.052536 & -115.3213 & -0.193124 & 0.058028 & 0.433816 \\
\hline \multirow[t]{3}{*}{ INFLATION } & $(0.08499)$ & (341.515) & $(0.16226)$ & $(0.04851)$ & $(0.17715)$ \\
\hline & {$[-0.61811]$} & {$[-0.33768]$} & [-1.19020] & [1.19619] & [2.44884] \\
\hline & -7.188581 & 11490.66 & -3.353996 & 8.159770 & 0.300024 \\
\hline \multirow[t]{2}{*}{ Constant } & (4.90273) & (19699.5) & $(9.35966)$ & (2.79825) & (10.2186) \\
\hline & [-1.46624] & [ 0.58330$]$ & {$[-0.35835]$} & [ 2.91603] & [ 0.02936] \\
\hline
\end{tabular}

Note. Standard errors in ( ), t-statistics in [ ]. Source: Author's computation.

SMEs financing. The effect of economic growth and other control variables on SMEs financing is discussed in this section. Table 3 shows that economic growth has a positive relationship with SMEs financing, but the result is not significant. Also, a negative relationship exists between growth of money supply and SMEs financing. This is against the expected results. However, the result is not significant. A positive relationship 
exists between interest rate and SMEs financing. An increase in interest rate may increase the funds available to banks to lend, and thereby increasing credits made available to SMEs. The result is however not significant. In addition, inflation has a negative relationship with SMEs financing. This is in line with the expected result but it is not significant.

Impulse response function. In this section, only the response of GDP to shock in other variables will be discussed. As shown in Figure 2, a positive shock on inflation will lead to a decline in GDP until the fourth period, and becomes marginally positive thereafter. Also, one positive shock in the growth of money supply will lead to a decline in GDP until sixth period, and remains marginally negative thereafter. However, a positive response from GDP is observed to a positive shock in SMEs financing throughout the periods though it became marginal after the fifth period. A similar result was also found in the response of GDP to shock in interest rate. The results were consistent with the VAR results.

\section{Diagnostic checks}

Stability test: The AR Roots Graph reports the inverse roots of the characteristic AR polynomial. The estimated VAR is stable if all roots lie inside the unit circle. Figure 6 shows that all roots lie inside the unit circle which is an indication that the VAR model is stable.

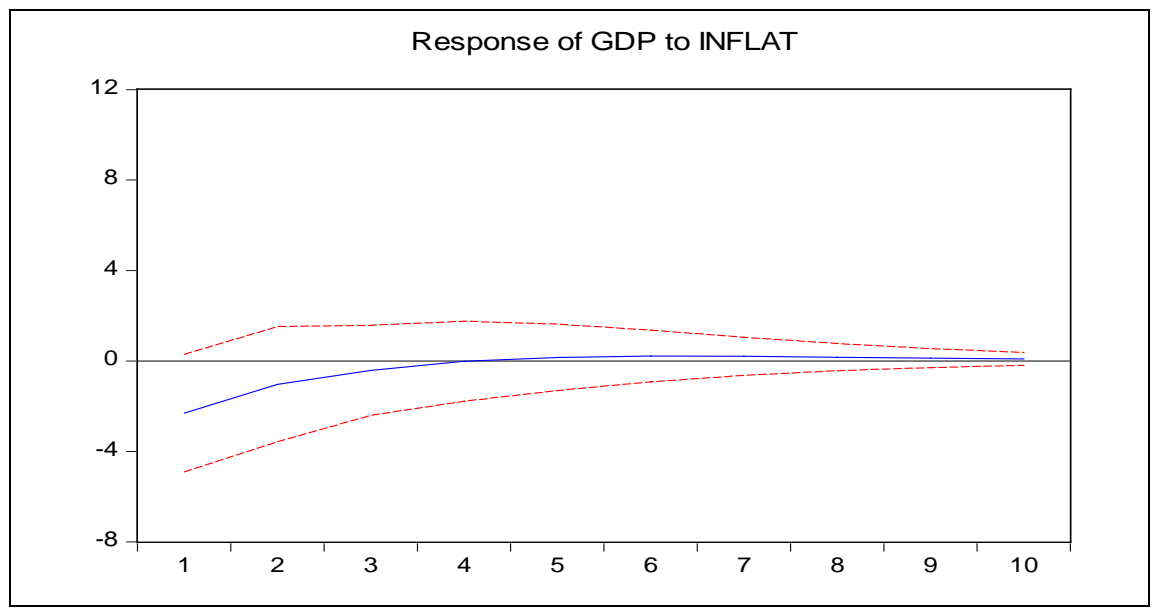

Figure 2. Response of GDP to shock in inflation.

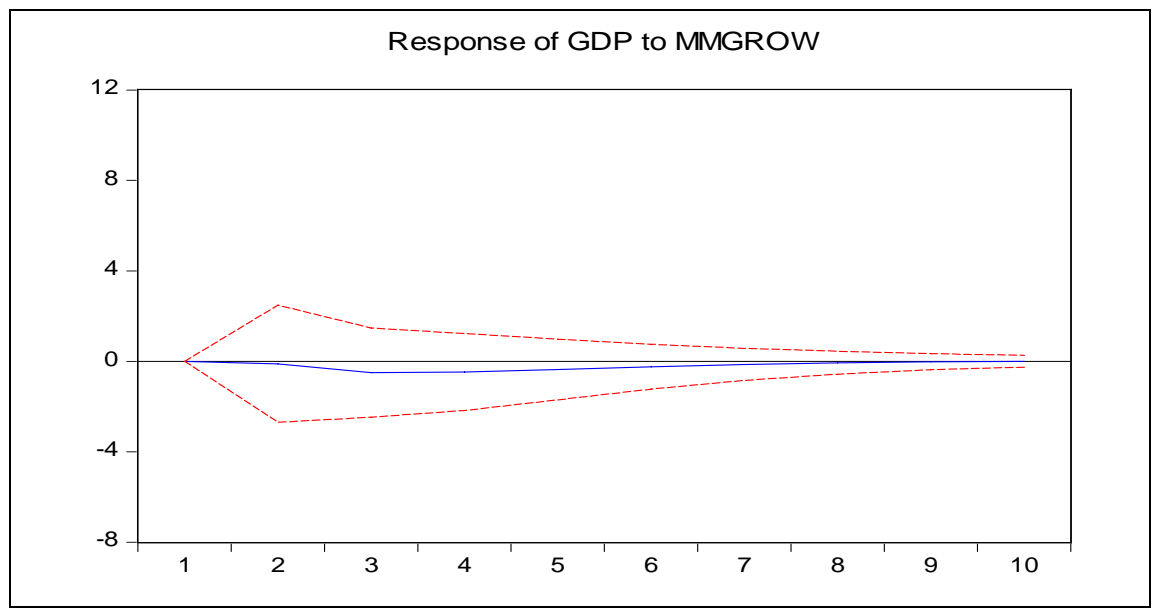

Figure 3. Response of GDP to shock in GMONEY. 


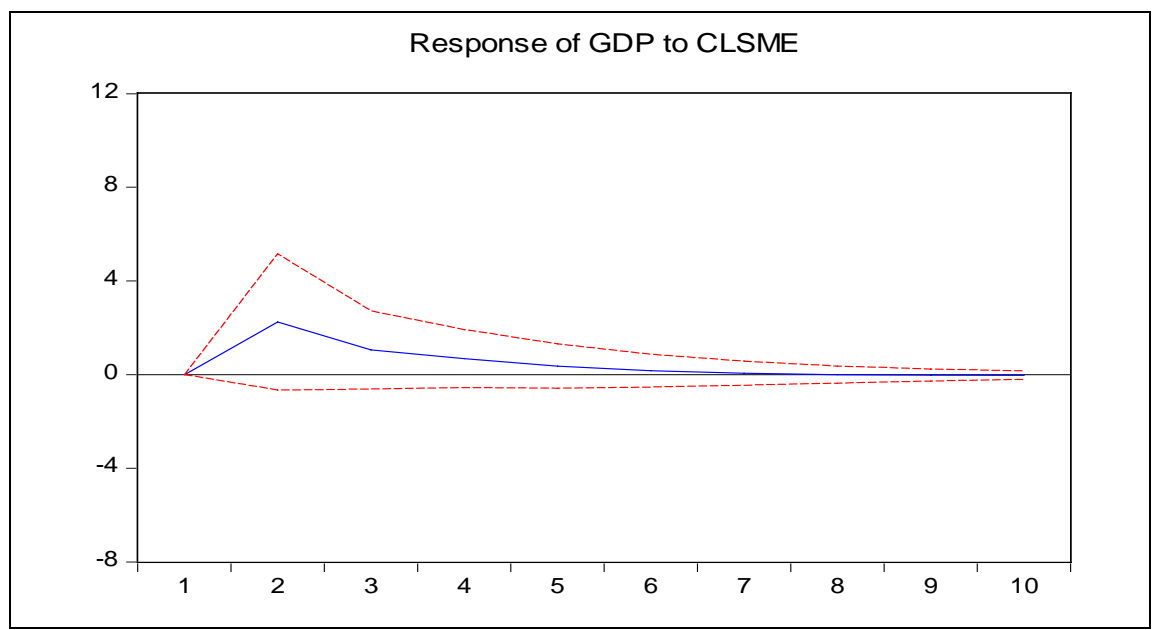

Figure 4. Response of GDP to shock in LCLSME.

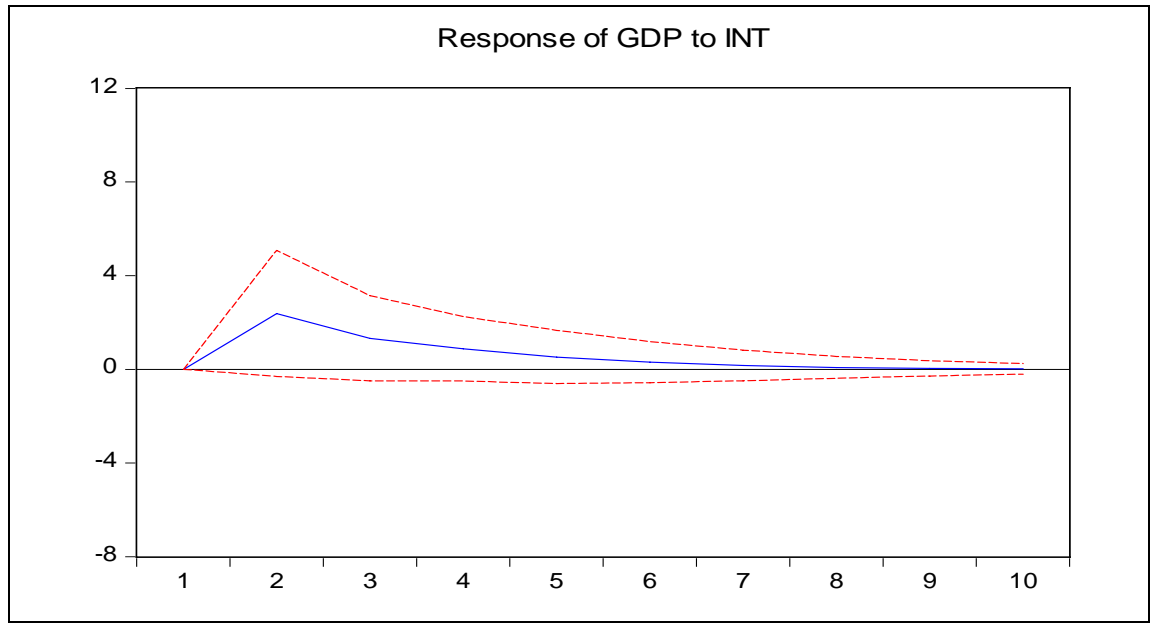

Figure 5. Response of GDP to shock in INT.

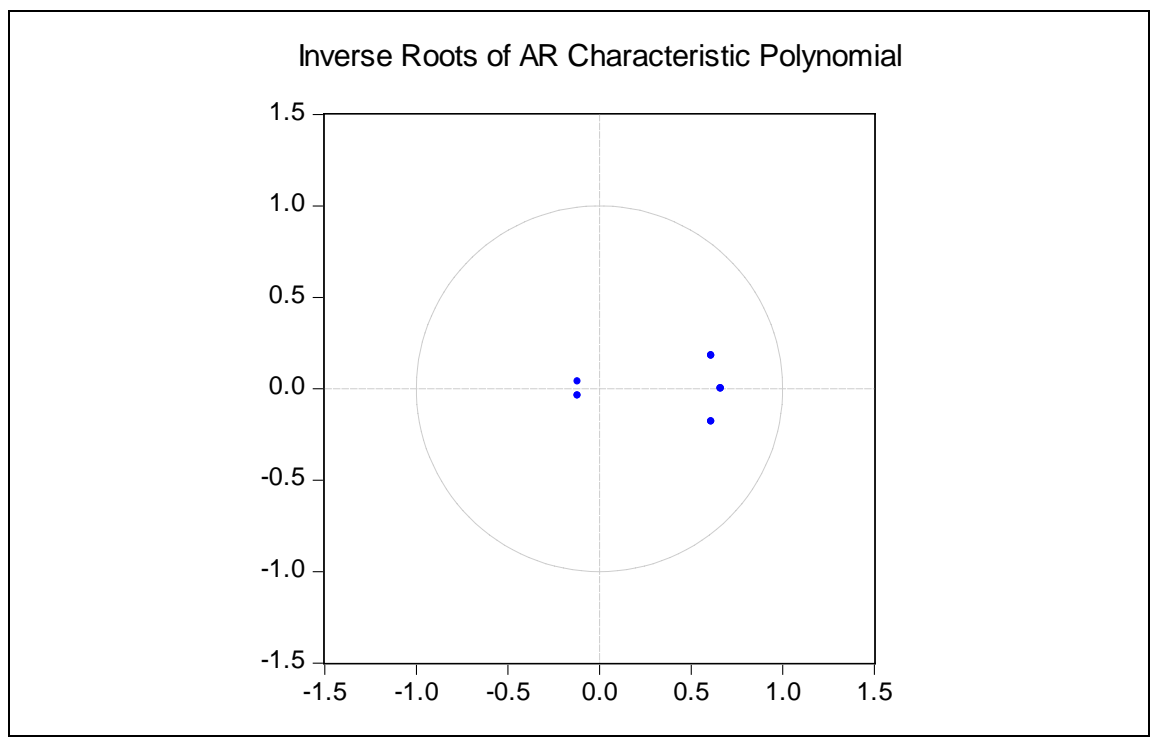

Figure 6. AR Roots Graph. 
Diagnostic checks: To validate the assumptions of the model, diagnostics checks wre conducted. The main residual checks conducted are the heteroscedasticity test, using White's test with no cross terms, and the serial correlation test which was tested using the Langrage Multiplier (LM) test. The Diagnostic test results are shown in Table 4 below:

Table 4

Diagnostics Checks

\begin{tabular}{llll}
\hline TEST & Null hypothesis & T-statistic & Probability \\
\hline White (Chi-sq.) & No conditional heteroscedasticity & 151.5145 & 0.4500 \\
Langrage Multiplier (LM) & No serial correlation & 20.05520 & 0.7439 \\
\hline
\end{tabular}

Source: Author's computation.

\section{Conclusion and Recommendation}

This paper was written to investigate the relationship between economic growth and SMEs financing in Nigeria. Vector autoregressive model was used in order to avoid the problem of endogeneity. ADF unit root test was used to ascertain the time series properties of the series. The result shows that all the series were stationary. Also, the result shows a positive relationship between SMEs financing and economic growth. Also, though inflation has a negative effect on SMEs financing, it still significantly influences economic growth. This paper therefore concludes with the recommendation that there is a need for government to intensify efforts to increase SMEs financing in the country. This can be done through introduction of a special intervention fund for SMEs in the country.

\section{References}

Abereijo, I. O., \& Fayomi, A. O. (2005). Innovative approach to SME financing in Nigeria: A review of small and medium industries equity investment scheme (SMIEIS). Journal of Social Sciences, 11(3), 219-227.

Adebisi, A., Sunday, G. C. A., \& Ofuani, A. B. (2015). Challenges of finance and the performance of small and medium enterprises (SMEs) in Lagos state. Developing Country Studies, 5(8), 46-57.

Afolabi, M. O. (2013). Growth effect of small and medium enterprises (SMEs) financing in Nigeria. Journal of African Macroeconomic Review, 3(1).

Akingunola, R. O. (2011). Small and medium scale enterprises and economic growth in Nigeria: An assessment of financing options. Pakistan Journal of Business and Economic Review, 2(1).

Aryeetey, E., \& Ahene, A. (2004). Changing regulatory environment for small-medium size enterprises and their performance in Ghana (CRC Working Paper, No. 30594). Centre on Regulation and Competition (CRC).

Business Statistics. (2016). Briefing paper number 06152. House of Common Library. Retrieved from http://www.parliament.uk/commons-library | intranet.parliament.uk/commons-library | papers@parliament.uk | @commonslibrary

Capital for Globalizing Companies. (2015). State of SME Finance in the United States in 2015. TradeUp Capital Fund and Nextrade Group, LLC Central Bank of Nigeria 2013 Statistical Bulletin. Abuja, Nigeria.

Ebiringa, O. T. (2011). Entrepreneurship venturing and Nigeria's economic development: The manufacturing sector in focus. Journal of Business Management \& Economic Research, 2(6), 376-381.

European Commission. (2003). Commission recommendation of 6 May 2003 concerning the definition of micro, small and medium-sized enterprises 12. Official Journal of the European Union, 124(36).

International Finance Corporation. (2006). Small and medium enterprises market reports.

Nwachukwu, A. C. (2012). The role of entrepreneurship in economic development: The Nigerian perspective. European Journal of Business and Management, 4(8), 96.

OECD. (2004). Promoting entrepreneurship and innovative SMEs in a global economy. Second OECD Conference of Ministers Responsible for SMEs (Executive Summary of the Background Reports). Istanbul. 
Olowe, F. T., Moradeyo, O. A., \& Babalola, O. A. (2013). Empirical study of the impact of microfinance bank on small and medium growth in Nigeria. International Journal of Academic Research in Economics and Management Sciences, $2(6), 116$.

Onugu, B. A. N. (2005). Small and medium enterprises (SMEs) in Nigeria: Problems and prospects (Unpublished Dissertation for a Doctor of Philosophy in Management Award). St. Clements University, Nigeria.

Okpara, J. (2011). Factors constraining the growth and survival of SMEs in Nigeria: Implications for poverty alleviation. Management Research Review, 34(2), 156-171.

Robu, M. (2013). The dynamic and importance of SMES in economy. USV Annals of Economics \& Public Administration, 13(1).

Safiriyu, A. M., \& Njogo, B. O. (2012). Impact of small and medium scale enterprises in the generation of employment in Lagos state. Kuwait Chapter of the Arabian Journal of Business and Management Review, 1(11), 107.

Savlovschi, L. I., \& Robu, N. R. (2011). The role of SMEs in modern economy. Economia, Seria Management, 14(1), $277-281$.

Small and Medium Enterprise Development Agency of Nigeria (SMEDAN) and National Bureau of Statistics. (2013). SMEDAN and National Bureau of Statistics collaborative survey (Selected Findings). Abuja, Nigeria

Subhan, Q. A., Mehmood, M. R., \& Sattar, A. (2013). Innovation in small and medium enterprises (SME’s) and its impact on economic development in Pakistan. International Business and Social Sciences Research Conference, 3-4. 